\title{
DOCUMENTATION OF HISTORICAL UNDERGROUND OBJECT IN SKORKOV VILLAGE WITH SELECTED MEASURING METHODS, DATA ANALYSIS AND VISUALIZATION
}

\author{
A. Dlesk ${ }^{\mathrm{a} *}$ \\ ${ }^{a}$ MSc. student at Department of Geomatics, Faculty of Civil Engineering, Czech Technical University in Prague \\ adam.dlesk@gmail.com \\ Commission V, WG V/2
}

KEY WORDS: Cultural heritage, photogrammetry, GPR, RPAS, 3D visualisation, laser scanning

\begin{abstract}
:
The author analyzes current methods of 3D documentation of historical tunnels in Skorkov village, which lies at the Jizera river, approximately $30 \mathrm{~km}$ away from Prague. The area is known as a former military camp from Thirty Years' War in 17th Century. There is an extensive underground compound with one entrance corridor and two transverse, situated approximately 2 to $5 \mathrm{~m}$ under the local development. The object has been partly documented by geodetic polar method, intersection photogrammetry, image-based modelling and laser scanning. Data have been analyzed and methods have been compared. Then the 3D model of object has been created and compound with cadastral data, orthophoto, historical maps and digital surface model which was made by photogrammetric method using remotely piloted aircraft system. Then the measuring has been realized with ground penetrating radar. Data have been analyzed and the result compared with real status. All the data have been combined and visualized into one 3D model. Finally, the discussion about advantages and disadvantages of used measuring methods has been livened up. The tested methodology has been also used for other documentation of historical objects in this area. This project has been created as a part of research at EuroGV. s.r.o. Company lead by Ing. Karel Vach CSc. in cooperation with prof. Dr. Ing. Karel Pavelka from Czech Technical University in Prague and Miloš Gavenda, the renovator.
\end{abstract}

\section{INTRODUCTION}

\subsection{The Skorkov town}

Skorkov with its 583 inhabitants $(\mathrm{CSO}, 2015)$ is a town lies approximately $30 \mathrm{~km}$ north-east from Prague, the capital of the Czech Republic. The main sight in Strokov is the St. Jan Krrtitel Church (the first record in 1359) with ossuary and the altar in the Renaissance style and the adjacent parish from 1910, (joined together with near village Sojovice). The town is very popular and often visited by cyclists and thanks to the magnificent river Jizera it is also a paradise for fish men. According to the locals, during The Thirty Years' War were two military camps divided by Jizera river - the Emperor's Army and Swedish Army. That is why during the local football matches could be the flags of these countries seen still today.

\subsection{Underground object beneath the former pub}

Near the St. Jan Krrtitel Church at the river there is a building (postcode number 18, parcel number 20) with the entrance to the extensive underground historical tunnels today used as a basement. The main corridor with vaulted circular shape is $20 \mathrm{~m}$ long and $2.3 \mathrm{~m}$ high. There are two transverses (both $10 \mathrm{~m}$ long) - right and left - at the end of this corridor. Both transverses are partially walled up. The right corridor extends underneath the load-bearing wall of a neighboring building number 14 and the ceiling is ruined. The height of its chimney is up to $5.5 \mathrm{~m}$ and $1.7 \mathrm{~m}$ underneath load-bearing wall. According to the local legend, these tunnels were used as emergency exits from the church to the river (former transport hub). However, this hypothesis has not been approved by the research. The tunnel is actually orientated to the different direction and after the extensive research, it has been found out that the end of the tunnel links to "nowhere" (no walling up or burying as was expected) so there is no way out. Likely it was used as a storeroom for army during the Thirty Years' War.

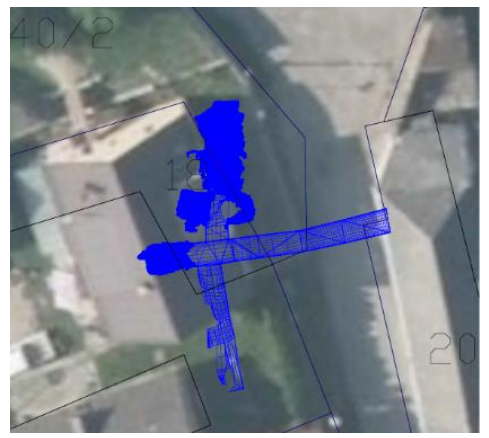

Figure 1. Cadastral map, orthophoto (COSMC, 2014) and geodetic survey of underground object.

\section{METHODOLOGY}

The aim of the research was to check the current situation of the underground object with using many geodetic and photogrammetric methods, laser scanning, RPAS (remotely piloted aircraft system) and ground penetrating radar (GPR), to collect surveying data with measuring under the surface and above surface and analyse those data. A part of the research 
was to find appropriate visualisation tool to merge all the acquired data and visualize them for presentation.

\subsection{Orthophoto and cadastral data}

The orthophoto with ground sampling distance with $25 \mathrm{~cm} /$ pix was obtained from Czech Office for Surveying, Mapping and Cadastre (COSMC) such as cadastral data of cadastral district Skorkov. Another orthophoto with ground sampling distance $5 \mathrm{~cm} /$ pix was created from RPAS data afterwards.

\subsection{Geodetic survey}

First of all the geodetic survey was conducted by creating five survey stations and their coordinates were identified in S-JTSK coordinate system using GNSS RTK method connected to system of permanent stations CZEPOS. The underground tunnels were measured with total station Topcon DS-Series in sections approximately after every $3.5 \mathrm{~m}$. Afterwards the planimetric and hypsographic surveys were made above the underground object and finally digital model of surface was created. The coordinates were computed in Kokeš software.

\subsection{Laser scanning}

Then measurement with laser scanner using phase based laser scanner Surphaser 25HSX was made. Phase based laser scanning principle is in measuring distances from phase shift between emitted and received waves on many wave lengths (Van Genechten, 2008). It is a very fast, precise and quiet laser scanner and is able to measure object up to $130 \mathrm{~m}$. During the measurement, 11 scans were merged and processed in Geomagic software. Then the mesh was created and georeferenced with points from mentioned geodetic survey.

\subsection{Ground penetrating radar}

The measuring with ground penetrating radar is non-destructive and non-invasive method. It allows the search and detection of different objects in generally homogeneous environments. The GPR is used for civil engineering needs (crack detection in concrete constructions or utilities engineering) or archaeology (archaeological site survey) and in many other fields. (Sala et al. 2012)

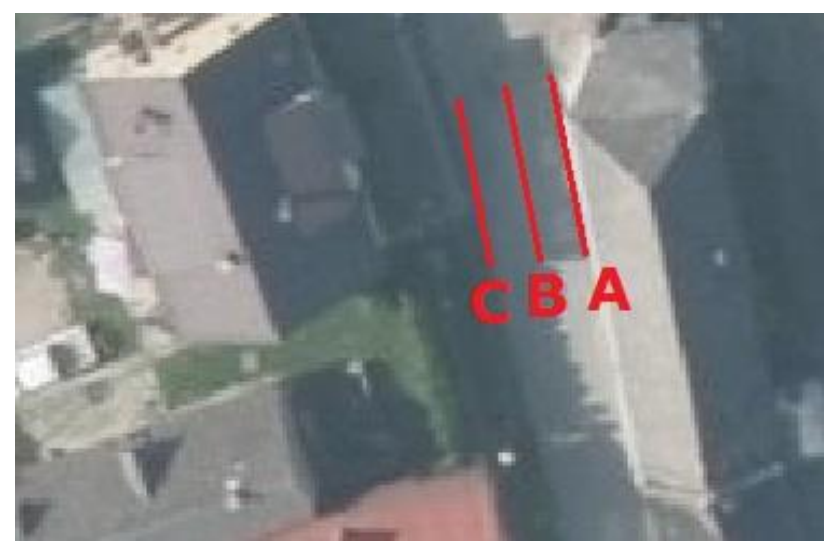

Figure 2. Measurement with GPR in sections A, B, C

With the ground penetrating radar SIR -3000 and $200 \mathrm{MHz}$ antenna, the measuring above the main corridor of the underground object in Skorkov was made in the three sections A, B, C. The interesting results were however found only in the section $\mathrm{A}$.

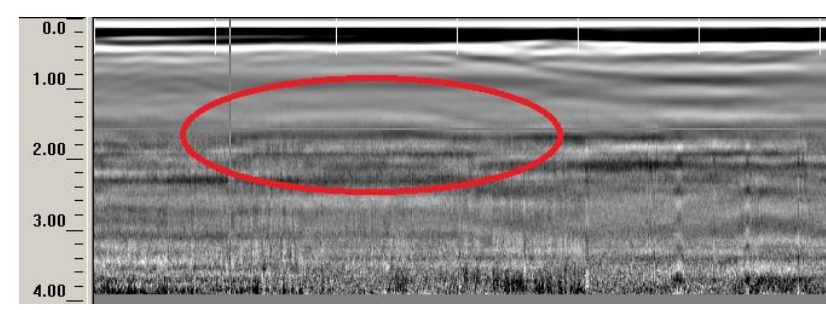

Figure 3. Scan of the ground penetrating radar where vaulted ceiling is being detected.

\subsection{RPAS and image based modelling}

Then the flight over the area of interest with fixed wing RPAS eBee (senseFly) and compact camera Canon IXUS 127 HS was made in purpose of creating digital model of surface. The flight was carried out during bad weather conditions and the quality of images however are little bit fuzzy. The 5 ground control points were measured using GNSS RTK method in S-JTSK coordinate system. Images were processed in Agisoft Photoscan software. Primarily the elements of exterior orientation were calculated. Then model was georeferenced with measured ground control points with following RMS errors.

\begin{tabular}{|l|c|c|c|}
\hline & $\mathrm{X}[\mathrm{m}]$ & $\mathrm{Y}[\mathrm{m}]$ & $\mathrm{Z}[\mathrm{m}]$ \\
\hline RMS & 0.04 & 0.04 & 0.15 \\
\hline
\end{tabular}

Table1. RMS errors.

Afterwards the dense point cloud and mesh with texture was created and final mesh was exported.

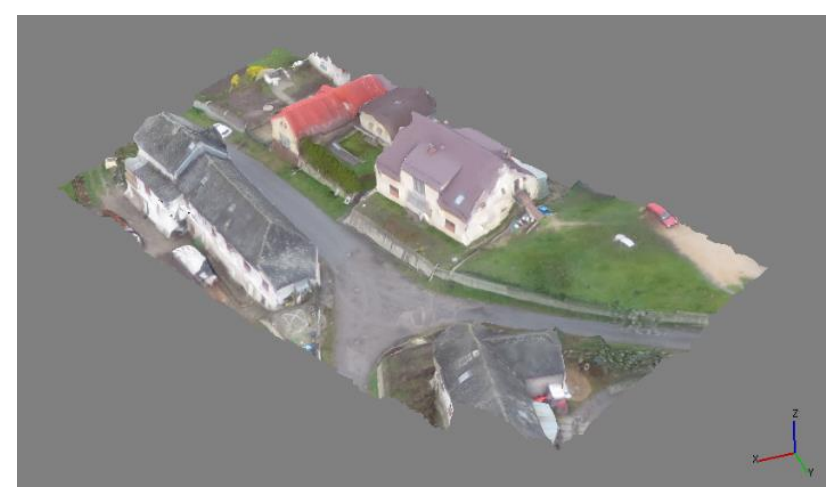

Figure 4. The textured digital model of surface.

The photos of niches that cannot be geodetically measured were taken. From acquired photos model of niches were created in Agisoft Photoscan. Models of niches were scaled with diagonal sizes and georeferenced on geodetic survey.

\subsection{Data merging and visualization}

All of the data were merged in Rhinoceros 3D software which allows to process wide variety of $2 \mathrm{D}$ and $3 \mathrm{D}$ formats including their textures. The 2D sections of all data were made in Rhinoceros 3D.

Data were visualized on Sketchfab. The Sketchfab is a net service where is the possibility to upload and share 3D data and browse models in the most internet browsers. The Sketchfab also supports more than $303 \mathrm{D}$ formats. 


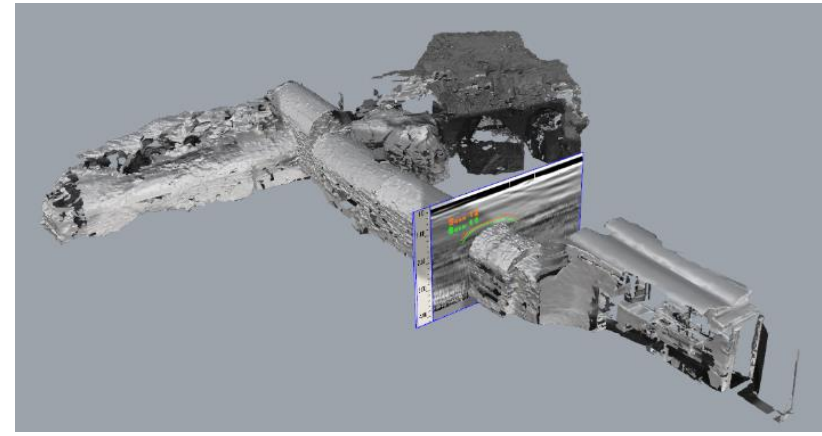

Figure 5. Laser scanning data and ground penetrating radar data.

\section{ANALYSIS}

3.1 Comparison of data acquired with ground penetrating radar, laser scan and geodetic measurement.

The results of ground penetrating radar from section A were imported to the laser scanner and geodetic measurement in Rhinoceros 3D software. The curves which probably shows vault ceiling of main corridor of underground object were deducted from the ground penetrating data. Section A was made through models based on laser scanning measurement and geodetic measurement as well. Those curves are compared in Figure 6.

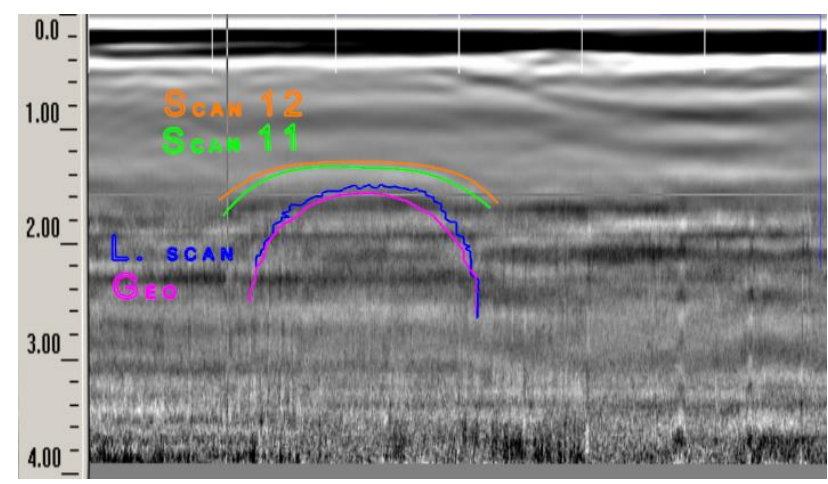

Figure 6. Ground penetrating data with sections threw models created from laser scanning data and geodetic measurement.

According to Figure 6., the depth of vault ceiling acquired by geodetic measurement and laser scanning differ to results of ground penetrating data about $0.2 \mathrm{~m}$. This could be caused by ignorance of subsoil material and not determinated accurate electromagnetic feature which should be inputted to the ground penetrating radar before measurement.

\subsection{Comparison between laser scanning data and data acquired with geodetic measurement.}

Finally it was calculated how georeferenced mesh based on laser scanning point cloud fit to the model made from geodetic measurement on main corridor of underground object. The 45846 points form point cloud were tested with mean $0.07 \mathrm{~m}$. The laser scanner unlike geodetic measurement has captured also portable objects which laid in tunnel and structure of walls and vault ceiling.

\begin{tabular}{|c|c|}
\hline Total points & 45846 \\
\hline Mean & $0,07 \mathrm{~m}$ \\
\hline Median & $0,04 \mathrm{~m}$ \\
\hline Standard deviation & $0,08 \mathrm{~m}$ \\
\hline
\end{tabular}

Table 2. Statistics of comparison laser scanning and geodetic measurement.

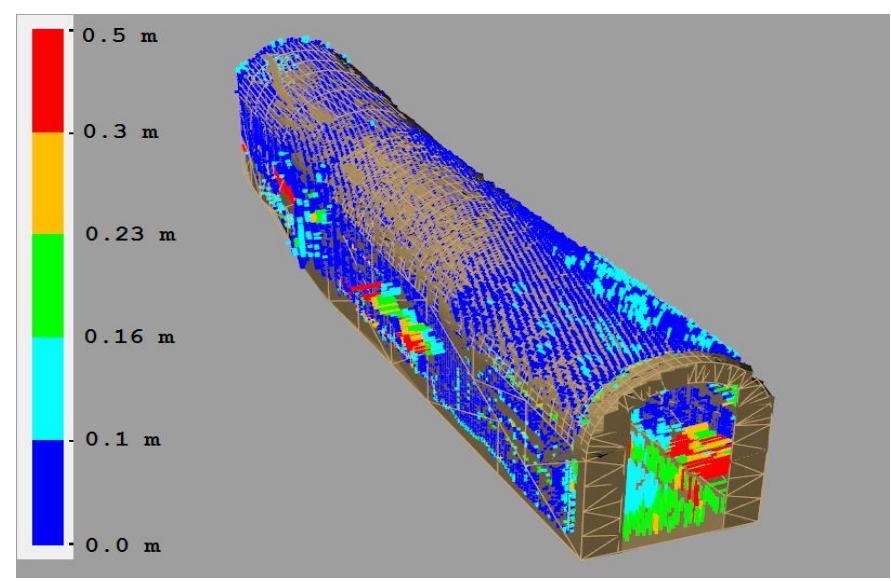

Figure 7. Visualization of difference between the model created based on laser scanning data and geodetic measurement.

\section{CONCLUSION}

In Skorkov village the underground object was measured by several methods. First of all, the model was made based on geodetic measurement by combination of image based modelling. In next phase the object was measured with laser scanner and model was georeferenced to measured coordinates. Those two models were compared. On Figure 7 is obvious that most of differences are up to $0.1 \mathrm{~m}$. The ground penetration measurement was made in three sections, however the reasonable results are only from the section A, where is possible to determine vault ceiling of underground object on the radar scan. The GPR data were merged with laser scanning and geodetic measurement and it is possible to state that those data is different in $0.2 \mathrm{~m}$ (Figure 6) in depth, but position seems accurate. Afterwards photos of area was captured by RPAS fixed wing eBee and from acquired data the digital model of surface was created. The flight was made during the bad weather conditions and that is the reason why model seems deformed in few places e.g. roofs of buildings.

This project was created as a part of internal research of EuroGV s.r.o. company lead by Ing. Karel Vach CSc.

\section{REFERENCES}

Czech statistical office, Population of Municipalities - 1 January 2015,https://www.czso.cz/documents/10180/20556287/1300721 503.pdf/33e4d70e-e75f-4596-930c-63406c9068d0?version=1.1

Faltýnová, M., Pavelka, K., Nový, P., and Šedina, J.: Complex Archaeological Prospection Using Combination of Nondestructive Techniques, Int. Arch. Photogramm. Remote Sens. Spatial Inf. Sci., XL-5/W7, 141-146, doi:10.5194/isprsarchivesXL-5-W7-141-2015, 2015.

Roger Sala, Ekhine Garcia and Robert Tamba (2012). Archaeological Geophysics - From Basics to New Perspectives, Archaeology, New Approaches in Theory and Techniques, Dr. 
Imma Ollich-Castanyer (Ed.), ISBN: 978-953-51-0590-9, InTech, Available from:

http://www.intechopen.com/books/archaeology-newapproachesin-theory-and-techniques/archaeological-geophysics-from-

basics-to-new-perspectives

Van Genechten, B.; Caner, H.; Poelman, R.; Heine, E.; Lerma, J.L.; Reiner, H.; Biosca Taronger, J.M.; De Bruyne, M.; Hankar, M. Theory and practice on Terrestrial Laser Scanning-Training material based on practical applications; Santana Quintero, M., Lerma, J.L, Heine, E., Van Genechten, B, Eds.; Vlaams Leonardo Da Vinci Agentschap v.z.w.: Valencia, Spain, Universidad Politecnica de Valencia Editorial 2006-2008 